\title{
Twisted steel-induced penetrating head injury
}

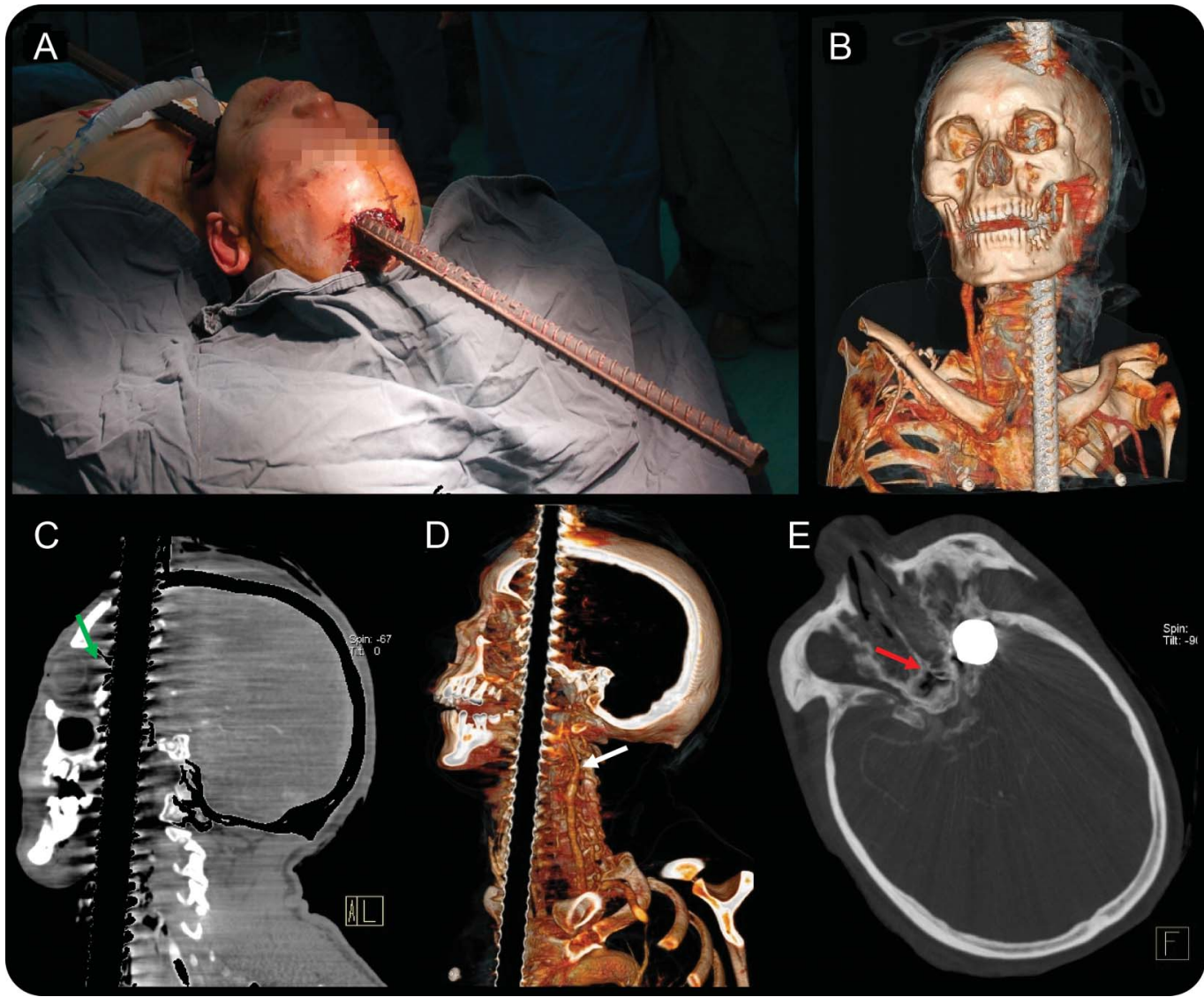

A twisted steel bar (1 m long with a diameter of $2.5 \mathrm{~cm}$ ) was inserted into the head of patient (A, B). CT scans show the location of steel bar, left side of optic canal ( $C$, green arrow), internal carotid artery ( $D$, white arrow), and cavernous sinus ( $E$, red arrow).

Penetrating head injury causes complex injuries and high mortality. ${ }^{1}$ A 47 -year-old man presented after a fall from a 4-meter-high construction scaffold with a twisted steel bar in his head (figure, A and B). The only focal neurologic deficit was a fixed and dilated left pupil. CT imaging revealed interruption of left optic canal (figure, C) without involvement of left internal carotid artery (figure, D) or cavernous sinus (figure, E). After a combined neurosurgical and maxillofacial operation, the patient recovered without intracranial infection or abscess, CSF leakage, or epilepsy. Except for left eye blindness, no neurologic sequelae were observed 1 month after surgery.

Peng Luo, MD, Zhou Fei, PhD, MD

From Xijing Hospital, Fourth Military Medical University, Xi’an, P.R. China.

Author contributions: Peng Luo: drafting/revising the manuscript, analysis or interpretation of data, accepts responsibility for conduct of research and final approval, acquisition of data. Zhou Fei: drafting/revising the manuscript, study concept or design, analysis or interpretation of data, accepts responsibility for conduct of research and final approval, study supervision.

Study funding: No targeted funding reported.

Disclosure: The authors report no disclosures relevant to the manuscript. Go to Neurology.org for full disclosures.

Correspondence to Dr. Fei: zhoufei@fmmu.edu.cn

1. Ratiu P, Talos I. Images in clinical medicine: the tale of Phineas Gage, digitally remastered. N Engl J Med 2004;351:e21. 


\section{Neurology}

\section{Twisted steel-induced penetrating head injury \\ Peng Luo and Zhou Fei \\ Neurology 2015;84;1909 \\ DOI 10.1212/WNL.0000000000001544}

\section{This information is current as of May 4, 2015}

\section{Updated Information \& Services}

\section{References}

Subspecialty Collections

\section{Permissions \& Licensing}

\section{Reprints}

including high resolution figures, can be found at: http://n.neurology.org/content/84/18/1909.full

This article cites 1 articles, 0 of which you can access for free at: http://n.neurology.org/content/84/18/1909.full\#ref-list-1

This article, along with others on similar topics, appears in the following collection(s):

\section{Brain trauma}

http://n.neurology.org/cgi/collection/brain_trauma

\section{Critical care}

http://n.neurology.org/cgi/collection/critical_care

\section{CT}

http://n.neurology.org/cgi/collection/ct

Information about reproducing this article in parts (figures,tables) or in its entirety can be found online at:

http://www.neurology.org/about/about_the_journal\#permissions

Information about ordering reprints can be found online:

http://n.neurology.org/subscribers/advertise

Neurology ${ }^{\circledR}$ is the official journal of the American Academy of Neurology. Published continuously since 1951, it is now a weekly with 48 issues per year. Copyright (C 2015 American Academy of Neurology. All rights reserved. Print ISSN: 0028-3878. Online ISSN: 1526-632X.

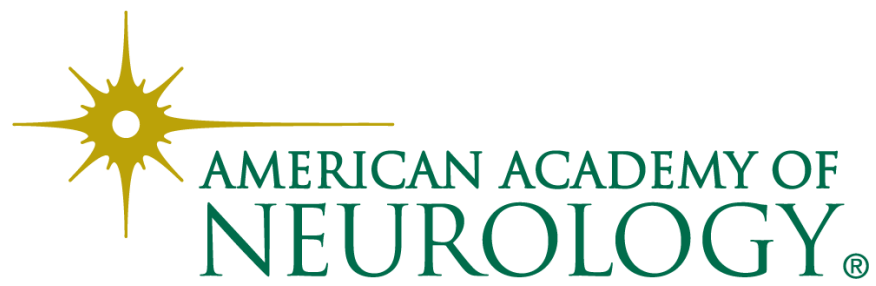

